\title{
Eggplant seedlings production in modified growing media by some organic wastes
}

\author{
Mahmoud M. G., Ahmad M. E., Younes N. A.* \\ Horticulture Department, Faculty of Agriculture, Al-Azhar University, Assiut, Egypt
}

\begin{abstract}
This study was conducted on the eggplant (Solanum melongena L.) at a private nursery in, Akhmim city, Sohag, Egypt located at $26^{\circ} 34^{\prime} 0^{\prime \prime} \mathrm{N}, 31^{\circ} 45^{\prime} 0^{\prime \prime}$ E. During the two successive winter seasons of 2019 and 2020, to evaluate the responses of the eggplant seeds' emergence, seedlings growth, that growing in modified growth media by using some organic wastes. $0.0,5,10$ and $15 \%$ of Moringa wastes were added to traditional media on a weight basis and $0.0,15,30$ and $45 \%$ of broccoli wastes also were added to traditional media on a weight basis. The experiment was laid out as a Completely Randomize Design with three replications. Results related to germination percentage $\%$, mean germination time, total chlorophyll content, seedling height $(\mathrm{cm})$, stem thickness $(\mathrm{mm})$ and seedling fresh and dry weight $\mathrm{g}$ revealed that, positively significant effects of partially replacement of traditional growing media with organic alternatives i.e. moringa and broccoli wastes. Among different combinations of mixtures growing medium, traditional media (peatmoss/vermiculite 1:1) plus moringa wastes on a weight basis 85:15 $\left(\mathrm{T}_{4}\right)$ respectively, or by adding broccoli wastes on a weight basis 70:30 $\left(\mathrm{T}_{3}\right)$ respectively, were the best selection compared to the control treatment and the other combination mixtures.
\end{abstract}

Keywords: seedling production, organic wastes, eggplant, traditional media. 


\section{Introduction}

Currently, vegetable production systems have been changed to improve yield and quality, leading to an improvement in sustainability. In horticultural cultivation, one of the most important sectors is the seedling production in nurseries. In the past, horticultural seedlings were produced directly by farmers. Nowadays, industria-lized nurseries provide seedlings characterized by a uniform growth and an early and contemporaneous development. In addition, consumer concern about the impact of food production on the environment is driving an increased demand for organic vegetables with a consequent increase of agricultural land cultivated by organic or modern agriculture methods. Hence, there is a need to produce high-quality seedlings suitable to be cultivated both in conventional and in organic farming systems. Growing media management, for improving seedling quality of traditional and organic horticultural crops, remains largely unexploited. Seedling production is an important step that influences crop yield in vegetable production systems. The growing media play a critical role in the propagation of vegetable seedlings in nurseries and greenhouses because they provide water, air, nutrients and also support plants. To enhance uniform germination and seedling development in vegetable production systems, it is important to use growing medium with appropriate physical and chemical properties. A variety of growing media produced from different sources are used in the production of vegetables worldwide (Mathowa et al., 2016). Some are natural in origin and others are produced artificially in factories (Bhat et al., 2013; Olle et al., 2012; Verdonck et al., 1982). Growing media used in the production of seedlings in nurseries include organic materials such as peat, tree bark, compost, coconut fiber, vermicompost, rice hush ash or inorganic materials such as perlite or vermiculite (Grunert et al., 2008; Nair et al., 2011; Vaughn et al., 2011). These growing substrates consist of either a single component or mixtures which support plants by providing water, air and nutrients (Abad et al., 2002; Bilderback et al., 2005; Olaria et al., 2016; Oagile et al., 2016; Yilmaz et al., 2014). The main goal of mixing materials in specific proportions is to eliminate the problems that may arise by combining the superior properties of materials. For example, the water-holding capacity can be increased by using inorganic and organic media at certain ratios which eliminate problems related to nutrition (Albaho et al., 2009; Gutierrez et al., 2012; Johnson, 2010). However, different growing media vary greatly in composition, particle size, $\mathrm{pH}$, aeration and ability to hold water and nutrients (Oagile et al., 2016). An eligible growth media must provide a secure growth substrate, enough nutrients and water, and permit oxygen absorbed by the roots as well as gas exchange freely through the growth media mixtures (Tam and Wang, 2015). They should preferably have organic sources which are more easily returned to nature and be relatively inexpensive or available to reduce production costs (Delshad et al., 2011). Also, they should be by-products of other industries or agricultural production systems which are produced, and their 
cycling can decrease costs or help in environmental sustainability. A good growing media provides sufficient anchorage or support to the plant, serves as a reservoir for nutrients and water, allows oxygen to diffuse to the roots and permits gaseous exchange between the roots and growth media. Nurseries use various growing media in the production of transplants, and the quality of growth media may also be defined in terms of its feasibility for the intended use and according to the climatic condition of the production area (Hasandokht and Nosrati 2010; Schmilewski 2009). For this reason, a wide number of chemical, physical, biological, and economic characteristics of the constituents must be considered when developing media formulations (Schmile-wski, 2009). A successful growth media must perform under practical conditions and constraints equal or better as a commercially available standard to be accepted by growers. They suggested that any new material should be tested in a commercial context before conducting detailed studies on the performance of Barraett et al. (2016). The testing of different kinds of agro-industrial by-products, to obtain alternative materials and fertilizers for agricultural productions, were investigated by several researchers (Antón et al., 2012; Gruda., 2009). Using waste material and plant remains in commercial transplants production has the benefits of reducing negative impacts on the environment for uncontrolled harvesting of peat, the accumulation of waste and has economic advantages of lower cost compared to other common growth media (Youssefian et al., 2009).
Therefore, exploration of the localized formula for matrix with easily taken material and low price has received widespread attention at home and abroad (Jeong 2001; Hummel et al., 2000). Studies showed that solid wastes from agricultural farming and breeding industry could be used as high valueadded matrix and formulated as composite substrates which achieved certain physicochemical property standards to replace coir and peat and to be used for vegetables' tray seedling cultivation. Many studies also showed that some materials, such as cottonseed hull, saw dust, carbonized rice hull, a sugar residue, sludge and waste material, etc., could be used for matrix of seedling cultivation (Lin et al., 2011). Thus, the aim of this study is to evaluate the partially substitution of peat moss in growing media and its effects on eggplant crop seedlings production.

\section{Materials and methods}

\subsection{Experimental site}

The experiment was performed on eggplant (Solanum melongena L.), pepper (Capsicum annum L.) and tomato (Solanum lycopersicum L.) at a private nursery in Akhmim city, Sohag, Egypt located at $26^{\circ} 34^{\prime} 0^{\prime \prime} \mathrm{N}, 31^{\circ} 45^{\prime} 0^{\prime \prime} \mathrm{E}$ during the two successive winter seasons of 2019 and 2020, to evaluate the partially substitution of peat moss in growing media and its effects on eggplant crop seedlings production. 


\subsection{Experimental materials}

\subsubsection{Plant material}

Three solanaceae crops were conducted for the present investigation i.e., eggplant, Solanum melongena L., (GALINE $F_{1}$ importer, World of Agriculture \& Veterinary Co-Wavco / Egypt, Thailand).

\subsubsection{Growth media materials}

At the beginning of the experiment, raw materials required to form the growth media for Solanaceae crop seedlings were collected from different sources. Peatmoss were purchased from the commercial market. Moreover, moringa and broccoli wastes was collected from the farm of the faculty of agriculture, Al-
Azhar University, Assuit Egypt, and then cleaned, air dried and crushed into small pieces.

\subsubsection{Composition of growth media}

Four combinations on a weight basis were prepared for each waste material. The suggested combinations and the percentage of each substrate are as shown in Tables (1) and (2). The growth media include different combinations of one mineral component, vermiculite $(\mathrm{V})$ and /or tow organic components moringa waste (MW) and broccoli waste (BW) at different ratios on a weight basis compared to the traditional media (TM, enriched peat moss) as a control treatment (C) (peatmoss: vermiculite $1: 1)$.

Table (1): Percentage of components used in preparing the treatments.

\begin{tabular}{|c|c|c|c|}
\hline No. of treatment & Traditional peatmoss media & Moringa wastes & Total (\%) \\
\hline $\mathrm{T}_{1}$ & 100 & ---- & 100 \\
\hline $\mathrm{T}_{2}$ & 95 & 5 & 100 \\
\hline $\mathrm{T}_{3}$ & 90 & 10 & 100 \\
\hline $\mathrm{T}_{4}$ & 85 & 15 & 100 \\
\hline
\end{tabular}

Table (2): Percentage of components used in preparing the treatments.

\begin{tabular}{|c|c|c|c|}
\hline No. of treatment & Traditional peatmoss media & Broccoli wastes & Total (\%) \\
\hline $\mathrm{T}_{1}$ & 100 & --- & 100 \\
\hline $\mathrm{T}_{2}$ & 85 & 15 & 100 \\
\hline $\mathrm{T}_{3}$ & 70 & 30 & 100 \\
\hline $\mathrm{T}_{4}$ & 55 & 45 & 100 \\
\hline
\end{tabular}

\subsubsection{Experimental design}

Greenhouse study was conducted in winter of 2019 and 2020 to evaluate the 
suitability and efficient of new growth media for growing the eggplant seedlings and compare them to commercial media. A randomized complete block design and four treatments were carried out with three replicates and seven measurements per replication were practiced.

\subsubsection{Eggplant seeds emergency}

In the greenhouse, the seeds were sowed in Styrofoam seed trays $(38 \mathrm{~cm}$ wide $\times$ $66 \mathrm{~cm}$ length $\times 7 \mathrm{~cm}$ depth) consist of 209 cells $(2 \times 2 \mathrm{~cm})$ which were filled with different the growth media treatments, then one seed was planted in each cell. Seed Trays ere irrigated with tap water then covered with black plastic sheet for 5 days. Seed trays were randomly distributed within the experiment and rotated once a week until the end of the experiment. The seedlings were irrigated with distilled water equally for all treatments according to their demand for water. The nutrient solution was prepared and used during the transplants' growth period. Throughout the growth period of eggplant transplants all general practices such as the irrigation rate, temperature, humidity, pest control as well as spraying with fertilizers or protection for all treatments were similar. The average temperature of day and night was 20 and $15{ }^{\circ} \mathrm{C}$ respectively.

\subsubsection{Data collection and analysis}

After one day from planting, the data of main germination traits were recorded and then calculated based on the published work of Dawood and Azooz (2019) which adopted by Ranal et al. (2009) as the following:

$$
\begin{aligned}
& \text { Germinability } \%=\frac{\text { Number of germinated seeds }}{\text { Total number of seeds }} \times 100 \\
& \text { Mean germination time }=\sum_{i=1}^{k} n_{i} t_{i} / \sum_{i=1}^{k} n_{i}
\end{aligned}
$$

Where $t_{i}$ : time of the germination beginning to the $\mathrm{i}^{\text {th }}$ observation (day or $\mathrm{h}) ; \mathrm{n}_{\mathrm{i}}$ : the number of seeds germinated in the time i (It indicates the number of germinated seeds correspondent to the $i^{\text {th }}$ observation, not cumulative number), k: the end of germination, St: standard deviation of the germination time and $t$ : mean germination time.

After 35 days from planting or when the plants reached to the size of commercial transplants, data recorded for each replication on twenty-five seedlings in the middle of each tray such as total chlorophyll content, seedling height $(\mathrm{cm})$, stem thickness $(\mathrm{mm})$ and seedlings fresh and dry weights g (dry weight was determined after oven drying at $70{ }^{\circ} \mathrm{C}$ for $48 \mathrm{~h})$.

\subsubsection{Statistical analysis}

Data were subjected to the statistical analysis of ANOVA, and the entries means were compared according to the least significant differences (LSD) at 5\% 
levels, as reported by Gomez and Gomez (1984). All statistical analysis was

\section{Results}

The effects of different media on germination traits i.e. germinability percentage $\%$ and mean germination time are summarized in Tables (3) and (4). According to the results of statistical analysis, there were significant differences at $p<0.05$ level between the media in respect of the germination ratio $\%$ and mean germination time in eggplant seeds. The positively trend for germination ratio and mean germination time was observed in $\mathrm{T}_{4}$ at mixtures with moringa and $\mathrm{T}_{3}$ at mixtures with broccoli performed with MCTAT computer software.

media in the first and second sowing date respectively. On the other hand, the lowest germination ratio and mean germination time was determined in $T_{1}$ (control treatment) media. highest relative leaf chlorophyll content values were observed in mixture media $15+85$ $\%$ of moringa wastes and traditional peatmoss media, respectively $\left(\mathrm{T}_{4}\right)$ or 30 $+70 \%$ of broccoli wastes and traditional peatmoss media $\left(\mathrm{T}_{3}\right)$, respectively in both sowing dates. Chlorophyll level gives an indirect estimate of the nutrient status, since most of the nitrogen is incorporated to the leaf chlorophyll (Table 5).

Table (3): Germinability percentages as affected by different studied growth media mixtures content for eggplant seedlings.

\begin{tabular}{|c|c|c|c|c|c|c|}
\hline \multirow{2}{*}{ Treatment } & \multicolumn{3}{|c|}{2019} & \multicolumn{3}{c|}{2020} \\
\cline { 2 - 7 } & Moringa & Broccoli & Means (a) & Moringa & Broccoli & Means (a) \\
\hline $\mathrm{T}_{1}$ & 96.0 & 86.9 & 91.1 & 93.9 & 89.9 & 91.9 \\
\hline $\mathrm{T}_{2}$ & 96.4 & 91.4 & 93.9 & 93.9 & 91.9 & 92.9 \\
\hline $\mathrm{T}_{3}$ & 95.4 & 92.4 & 93.9 & 95.0 & 92.3 & 93.7 \\
\hline $\mathrm{T}_{4}$ & 96.9 & 90.9 & 93.9 & 96.3 & 90.6 & 93.5 \\
\hline Means (b) & 96.18 & 90.2 & --- & 94.8 & 91.2 & --- \\
\hline LSD & $\mathrm{a}=1.18$ & $\mathrm{~b}=1.44$ & $\mathrm{ab}=1.86$ & $\mathrm{a}=1.58 \quad \mathrm{~b}=1.67 \mathrm{ab}=1.02$ \\
\hline
\end{tabular}

Table (4): Mean germination time as affected by different studied growth media mixtures content for eggplant seedlings.

\begin{tabular}{|c|c|c|c|c|c|c|}
\hline \multirow{2}{*}{ Treatment } & \multicolumn{3}{|c|}{2019} & \multicolumn{3}{c|}{2020} \\
\cline { 2 - 7 } & Moringa & Broccoli & Means (a) & Moringa & Broccoli & Means (a) \\
\hline $\mathrm{T}_{1}$ & 7.75 & 7.84 & 7.79 & 7.36 & 7.78 & 7.57 \\
\hline $\mathrm{T}_{2}$ & 6.94 & 5.24 & 6.09 & 6.43 & 5.74 & 6.09 \\
\hline $\mathrm{T}_{3}$ & 5.94 & 5.20 & 5.57 & 5.99 & 5.19 & 5.59 \\
\hline $\mathrm{T}_{4}$ & 4.87 & 6.56 & 5.72 & 4.32 & 6.76 & 5.54 \\
\hline Means (b) & 6.38 & 6.21 & --- & 6.03 & 6.37 & --- \\
\hline LSD & $\mathrm{a}=0.72$ & $\mathrm{~b}=0.03$ & $\mathrm{ab}=0.89$ & $\mathrm{a}=0.65$ & $\mathrm{~b}=0.02$ & $\mathrm{ab}=0.41$ \\
\hline
\end{tabular}


Table (5): Chlorophyll content as affected by different studied growth media mixtures content for eggplant seedlings.

\begin{tabular}{|c|c|c|c|c|c|c|}
\hline \multirow{2}{*}{ Treatment } & \multicolumn{3}{|c|}{2019} & \multicolumn{3}{c|}{2020} \\
\cline { 2 - 7 } & Moringa & Broccoli & Means (a) & Moringa & Broccoli & Means (a) \\
\hline $\mathrm{T}_{1}$ & 40.93 & 41.07 & 41.00 & 40.47 & 41.03 & 40.75 \\
\hline $\mathrm{T}_{2}$ & 41.90 & 43.80 & 42.85 & 45.10 & 44.40 & 44.75 \\
\hline $\mathrm{T}_{3}$ & 46.20 & 47.07 & 46.64 & 46.30 & 47.73 & 47.02 \\
\hline $\mathrm{T}_{4}$ & 48.66 & 38.63 & 43.65 & 48.40 & 34.60 & 41.50 \\
\hline Means (b) & 44.42 & 42.64 & --- & 45.07 & 41.94 & --- \\
\hline LSD & $\mathrm{a}=1.67$ & $\mathrm{~b}=1.38$ & $\mathrm{ab}=3.35$ & $\mathrm{a}=1.17$ & $\mathrm{~b}=1.57 \quad \mathrm{ab}=2.64$ \\
\hline
\end{tabular}

Data related to seedling height and stem thickness shows that the growing media $\mathrm{T}_{4}$ in mixtures with moringa wastes and $\mathrm{T}_{3}$ in mixtures with broccoli wastes gave the highest values of eggplant seedling height and stem thickness. The shortest and the thinnest seedlings were observed in control treatment $\mathrm{T}_{1}$ (peatmoss: vermiculite 1:1) (Tables 6 and 7). The shoot fresh and dry weights in the medium treatment (with moringa wases " $\mathrm{T}_{4}$ " and with broccoli wases " $\mathrm{T}_{3}$ ") had positive impact compared with some other mixtures medium (Tables 8 and 9). Eggplant seedlings that grown in the traditional media $\left(T_{1}\right)$, seem to be the lowest seedlings fresh and dry weight $g$ than the other mixtures media.

Table (6): Seedling height $(\mathrm{cm})$ as affected by different studied growth media mixtures content for eggplant seedlings.

\begin{tabular}{|c|c|c|c|c|c|c|}
\hline \multirow{2}{*}{ Treatment } & \multicolumn{3}{|c|}{2019} & \multicolumn{3}{c|}{2020} \\
\cline { 2 - 7 } & Moringa & Broccoli & Means (a) & Moringa & Broccoli & Means (a) \\
\hline $\mathrm{T}_{1}$ & 14.00 & 15.03 & 14.52 & 15.17 & 13.40 & 14.29 \\
\hline $\mathrm{T}_{2}$ & 14.33 & 15.93 & 15.13 & 16.67 & 14.33 & 15.05 \\
\hline $\mathrm{T}_{3}$ & 15.00 & 19.50 & 17.25 & 17.00 & 17.67 & 17.36 \\
\hline $\mathrm{T}_{4}$ & 19.68 & 15.33 & 17.51 & 19.67 & 12.33 & 16.0 \\
\hline Means (b) & 15.75 & 16.45 & --- & 17.13 & 14.43 & --- \\
\hline LSD & $\mathrm{a}=0.83$ & $\mathrm{~b}=0.57$ & $\mathrm{ab}=1.63$ & $\mathrm{a}=0.73$ & $\mathrm{~b}=1.04$ & $\mathrm{ab}=1.54$ \\
\hline
\end{tabular}

Table (7): Stem thickness ( $\mathrm{mm})$ as affected by different studied growth media mixtures content for eggplant seedlings.

\begin{tabular}{|c|c|c|c|c|c|c|}
\hline \multirow{2}{*}{ Treatment } & \multicolumn{3}{|c|}{2019} & \multicolumn{3}{c|}{2020} \\
\cline { 2 - 7 } & Moringa & Broccoli & Means (a) & Moringa & Broccoli & Means (a) \\
\hline $\mathrm{T}_{1}$ & 2.33 & 2.56 & 2.45 & 2.42 & 2.39 & 2.41 \\
\hline $\mathrm{T}_{2}$ & 2.55 & 2.94 & 2.75 & 2.76 & 2.74 & 2.75 \\
\hline $\mathrm{T}_{3}$ & 2.98 & 3.03 & 3.01 & 3.00 & 2.99 & 2.99 \\
\hline $\mathrm{T}_{4}$ & 3.04 & 2.20 & 2.62 & 3.10 & 2.31 & 2.71 \\
\hline Means (b) & 2.73 & 2.68 & --- & 2.82 & 2.61 & --- \\
\hline
\end{tabular}




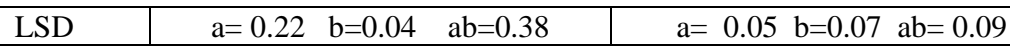

Table (8): Fresh weight (g) as affected by different studied growth media mixtures content for eggplant seedlings.

\begin{tabular}{|c|c|c|c|c|c|c|}
\hline \multirow{2}{*}{ Treatment } & \multicolumn{3}{|c|}{2019} & \multicolumn{3}{c|}{2020} \\
\cline { 2 - 7 } & Moringa & Broccoli & Means (a) & Moringa & Broccoli & Means (a) \\
\hline $\mathrm{T}_{1}$ & 2.37 & 2.44 & 2.41 & 2.48 & 2.65 & 2.57 \\
\hline $\mathrm{T}_{2}$ & 2.73 & 2.93 & 2.83 & 3.49 & 3.16 & 3.34 \\
\hline $\mathrm{T}_{3}$ & 3.90 & 4.10 & 4.00 & 4.52 & 4.35 & 4.44 \\
\hline $\mathrm{T}_{4}$ & 4.79 & 2.44 & 3.62 & 4.85 & 2.52 & 3.69 \\
\hline Means (b) & 3.45 & 2.98 & --- & 3.84 & 3.17 & --- \\
\hline LSD & \multicolumn{7}{|c|}{$\mathrm{a}=0.31 \quad \mathrm{~b}=0.56 \quad \mathrm{ab}=0.79$} & $\mathrm{a}=0.17$ & $\mathrm{~b}=0.24 \quad \mathrm{ab}=0.34$ \\
\hline
\end{tabular}

Table (9): Dry weight (g) as affected by different studied growth media mixtures content for eggplant seedlings.

\begin{tabular}{|c|c|c|c|c|c|c|}
\hline \multirow{2}{*}{ Treatment } & \multicolumn{3}{|c|}{2019} & \multicolumn{3}{c|}{2020} \\
\cline { 2 - 7 } & Moringa & Broccoli & Means (a) & Moringa & Broccoli & Means (a) \\
\hline $\mathrm{T}_{1}$ & 0.19 & 0.13 & 0.16 & 0.19 & 0.14 & 0.17 \\
\hline $\mathrm{T}_{2}$ & 0.31 & 0.25 & 0.28 & 0.37 & 0.22 & 0.30 \\
\hline $\mathrm{T}_{3}$ & 0.44 & 0.49 & 0.47 & 0.48 & 0.49 & 0.49 \\
\hline $\mathrm{T}_{4}$ & 0.50 & 0.28 & 0.39 & 0.54 & 0.24 & 0.39 \\
\hline Means (b) & 0.36 & 0.29 & --- & 0.40 & 0.27 & --- \\
\hline LSD & $\mathrm{a}=0.02 \quad \mathrm{~b}=0.03 \quad \mathrm{ab}=0.04$ & $\mathrm{a}=0.01 \quad \mathrm{~b}=0.04 \quad \mathrm{ab}=0.08$ \\
\hline
\end{tabular}

\section{Discussion}

Agriculture is the main source of providing food for human in terms of food security. Nowadays, the agriculture is faced with many problems such as affected by diseases lead to reduce yield and production. Also, there are many problems related to soil such as soil born pest, lack of fertile soil and water shortage. The problems in agricultural land use such as soil exhaustion, pest infestation or chemical interference are increasing greatly, nematode, heavy to handle and shipping to labor, weeds, and pathogens due to intensive cropping, injudicious application of pesticides or continuous monoculture (Asaduzzaman et al., 2013). It can provide several major advantages in the management of both plant nutrition and plant protection, with prevent and make the solution for those problems; there are many methods which can use organic and inorganic material, growing media influences seed germination and succeeding emergence and growth of seedlings in a nursery (Baiyeri and Mbah, 2006). In this regard, soilless culture can avoid problems with monoculture of plants in the same land for years (Alan, 1990). Usually peat moss characterized by low number of plant pathogens and weed seeds, which diminishes the risk of introduction of dissemination of soil-based pests (Reedy 2005). And it is a reservoir of moisture and plant nutrients (Grower, 1987). In addition, it influences the performance of 
seedling before they are transplanted in the field such as perlite, peat moss, vermiculite, rock wool, coconut coir, pelleted clay (Sevgican, 1999). According to Bilderback et al. (2005), the purpose of using those media is to provide enough nutrient for growing plant on it. In the present work, four mixtures growing medium have been used to compare between each media which one of these will have the more impact on eggplant seedling under greenhouse condition. The results reveal that seedling production of eggplant in modified traditional peatmoss media caused a significant increase in germinability percentage, mean germination time and vegetative growth as well as total chlorophyll content. The highest germination percentage, mean germination time, total chlorophyll content, seedling height, seedling stem thickness and seedling fresh and dry weight were observed, whereas peatmoss and traditional media were used in equivalent ratio $(15: 85)\left(\mathrm{T}_{4}\right)$ or when, broccoli wastes and traditional media were used in equivalent ratio $(30: 70)\left(\mathrm{T}_{3}\right)$. Our results were in line with various scientists, such as, Riaz et al. (2008), advocated use of different growing media for zinnia and suggested physical and chemical properties of media, like, structure, texture, $\mathrm{pH}$, as well as, nitrogen, phosphorus and potassium, as a dominant factor for the growth and development of plant. Furthermore, Ahmad et al. (2012) suggested that incorporation of rice hulls and press mud in traditional substrates improved the growth and quality indices and increased flower yield of Rosa hybrid L. cvs. 'Kardinal', 'Anjlique' and 'Gold Medal'. Results in this investigation revealed that, the increase in the amount of Moringa wastes added to the peatmoss media leads to an increase in the length of seedlings. Meanwhile, the increase in the amount of broccoli waste for more than $30 \%$ of the volume of the peatmoss media leads to a decrease in the length of seedlings at all Solanaceae crops under studies. There are reports that olive-mills waste composts could be used as replacement for peat in growing media. According to Urlic et al. (2015), they should be used in a rate not higher than $50 \%$ for Brassicas and not higher than $25 \%$ for lettuce and endive transplant production. Meantime, Ceglie et al. (2011) reports that treatments with $20 \%$ olive pomace compost showed the best performances of tomato seedlings, while $45 \%$ could be considered as the upper limits for producing satisfactory tomato seedlings. Similarly, grape-vinecompost can also be used in tomato transplant production in a rate of up to $40 \%$ (Kritsotakis and Kabourakis, 2011). The physical and chemical properties of different organic substrates are unique; therefore, each substrate should be characterized prior to partial replacement of container substrate to optimize plant growth. Atiyeh et al. (2001) and Subler et al. (1998) reported the incorporation of 5 and $10 \%$, respectively, vermicompost into container media improved growth of tomato transplants. Both Atiyeh et al. (2000) and Herrera et al. (2008) reported $30 \%$ replacement of commercial mix with vermicompost and municipal solid waste, respectively, enhanced tomato plant growth while greater amounts decreased plant growth. In studies by Lazcano et al. (2009) and Danaher et al. (2011), substitution of C50 \% container mix with alternative soilless substrates 
improved tomato transplant growth. Jahromi et al. (2012) reported commercial mix replaced with $\mathrm{C} 60 \%$ compost outperformed the peat-based substrate even though EC concentrations exceeded $3.5 \mathrm{mS} \mathrm{cm}^{-1}$. The process of vermicomposting tends to result in higher levels of plant availability of most nutrients than does the conventional composting process. Therefore, its presence in compost mixtures stimulates plant growth. Thus, a higher dry matter per plant and a higher relative growth rate was found by Babaj et al. (2009) and Arouiee et al. (2009) in tomato seedlings growing in a mixture of vermicompost with commercial peat (up to $50 \%$, vol:vol). Improved transplant quality in peppers and eggplants (up to 20\%, vol:vol), but not in tomato transplant was also reported by (Paul and Metzger, 2015). plant response to different substrates is strictly related to the tested species and also depends on the materials used and on the proportions in the mixtures and it is very complex to establish the most suitable materials and especially, the best proportions to obtain good results concerning plant growth and productivity (Ceglie et al., 2015). The use of compost into substrates in different ratios may cause some problems as a consequence of its high salt content, unsuitable physical properties (water holding capacity, aeration etc.), heavy metal toxicity and variable quality and composition (Chrysargyris et al., 2013; Fascella, 2015). Thus, examining the impact of municipal solid waste compost (MSWC) mixed with conventional peat substrates at various ratios, as a growth medium in the nursery production of melon (Chrysargyris et al., 2013) found that seed emergence enhanced when low MSWC content $(<30 \%)$ was used while increased MSWC content $(>60 \%)$ reduced (up to $80 \%$ ) emergence and delayed up to 6 days the emergence time. Under nursery conditions, addition of MSWC (especially in content greater than $30 \%$ ) reduced leaf numbers produced, seedling fresh weight (and dry matter content), chlorophyll and total carotenoids content. In similar experiments, (Chrysargyris, 2017) found that addition of $>30 \%$ MSWC reduced pepper seedling height, leaf number and fresh weight, while leaf chlorophyll and total carotenoids content decreased in > 60\% MSWC into the peat, and (Papamichalaki et al., 2014) found that low content $(15 \%$ to $30 \%$ ) of MSWC may act as an alternative substitute for peat in watermelon seedling production.

\section{Conclusion}

The exploitation of organic wastes and the $3 \mathrm{R}$ (reduce, reuse, and recycle) tendency of wastes have become of great interest and attractive due to the possible use of waste derived from industrial sectors for mineral application and/or soil improvement in agriculture. Greener and sustainable agriculture is promoting the peat savings restoration, and alternative growing media are searched for use in nurseries. Moringa and broccoli wastes is an auspicious alternative, which reflected the scope of the present study, to partial peat replacement for eggplant seedling production. The moringa and broccoli wastes-based media increased the germination traits and the seedling growth characteristics for the eggplant. Replacing 
the traditional media at a rate of $15 \%$ with moringa waste or $30 \%$ with broccoli waste represents the optimal mixture for the production of eggplant seedlings.

\section{References}

Abad, M., Noguera, P. and Bures, S. (2001), "National inventory of organic wastes for use as growing media for ornamental potted plant production: case study in Spain", Bioresource Technology, Vol. 77 No. 2, pp. 197-200.

Abad, M., Noguera, P., Puchades, R., Maquieira, A. and Noguera, V. (2002), "Physico-chemical and chemical properties of some coconut dusts for use as a peat substitute for containerized ornamental plants", Bioresource Technology, Vol. 82 No. 3, pp. 241-245.

Ahmad, I., Khan, M. A., Qasim, M., Zafar, M. S. and Ahmad, R. (2012), "Substrates effects on growth, yield and quality of Rosa hybrida L", Pakistan Journal of Botany, Vol. 44 No. 5, pp. 177-185.

Alan, R. (1990), Characteristics of some of the growth media used in greenhouse, Turkey 5, Greenhouse Symposium, Izmir, Turkey, pp. 401410.

Albaho, M., Bhat, N., Abo-Rezq, H. and Thomas, B. (2009), "Effect of Three Different Substrates on Growth and Yield of Two Cultivars", Europe Journal of Science Resource, Vol.
28 No. 2, pp. 227-233.

Antón, A., Torrellas, M., Montero, J.I. Ruijs, M., ermeulen, P.V. and Stanghellini, C. (2012), "Environmental impact assessment of Dutch tomato crop production in a Venlo glasshouse", Acta Horticulturae, Vol. 927 pp. 781791.

Arouiee, H., Dehdashtizade, B., Azizi, M. and Davarinejad, G.H. (2009), "Influence of vermicompost on the growth of tomato transplants", Acta Horticulturae, Vol. 809 pp. 147154.

Asaduzzaman, M., Mondal, F. M., Ban, T. and Asao, T. (2013), "Selection of ideal succeeding crops after asparagus, taro, and beans replanting field in seedling growth bioassay", Allelopathy Journal, Vol. 32 No. 2, pp. 1-22.

Atiyeh, R. M., Subler, S., Edwards, C. A., Bachman, G., Metzger, J. D. and Shuster, W. (2000), "Effects of vermicomposts and composts on plant growth in horticultural container media and soil", Pedo biologia, Vol. 44 pp. 79-590.

Atiyeh, R. M., Edwards, C. A., Subler, S. and Metzger, J. D. (2001), "Pig manure vermicompost as a component of a horticultural bedding plant medium: effects on physicochemical properties and plant growth", Bio Resource Technology, Vol. 78 pp. 11-20. 
Babaj, I. and Kaçiu, S. (2009), "The influence of different substrate composition on growth parameters and dry mass partitioning of cucumber (Cucumis sativum L.) seedlings", Acta Horticulturae, Vol. 830, pp. 419-424.

Baiyeri, K. P. and Mbah, B. N. (2006), "Effects of soilless and soil-based nursery media on seedling emergence, growth and response to water stress of African breadfruit (Treculia africana Decne)", African Journal Biotechnology, Vol. 5 No. 15, pp. 1405-1410.

Barraett, G. E., Alexander, P. G., Robindon, J. S. and Bragg, N. G. (2016), "Achieving environmentally sustainable growing media for soilless plant cultivation systems. A review", Scientia Horticulturae, Vol. 212, pp. 220-234.

Bhat, N. R., Suleiman, M. S., Thomas, B., Lekha, V. S., George, P. and Ali, I. S. (2013), "Growing substrate for organic lettuce production in Kuwait", World Journal of Agricultural Sciences, Vol. 9 No. 2, pp. 143-147.

Bilderback, T. E., Warren, S. L., Owen, J. S. and Albano, J. P. (2005), "Healthy substrates need physicals too", Horttechnology, Vol. 15 No. 4, pp. 747-751.

Ceglie F. G., Bustamante, M. A., Amara, M. B. and Tittarelli, F. (2015), "The challenge of peat substitution in organic seedling production: optimization of growing media formulation through mixture design and response surface analysis", PLOS ONE, Vol. 10 No. 6, pp. 114.

Ceglie, F. G., Elshafie, H., Verrastro, V. and Tittarelli, F. (2011), "Evaluation of olive pomace and green waste composts as peat substitutes for organic tomato seedling production", Compost Science \& Utilization, Vol. 19 No. 4, pp. 293 300.

Chrysargyris, A., Saridakis, C. and Tzortzakis, N. (2013), "Use of municipal solid waste compost as growing medium component for melon seedlings production", Journal of Plant Biology \& Soil Health, Vol. 1, pp. 1-5.

Chrysargyris, A., Stamatakis, A., Moustakas, K., Prasad, M. and Tzortzakis, N. (2017), "Evaluation of municipal solid waste compost and/or fertigation as peat substituent for pepper seedlings production", Waste and Biomass Valorization, Vol. 9 No. 9, pp. 2285-2294.

Danaher, J. J., Pantanella, E., Rakocy, J. E., Shultz, R. C. and Bailey, D. S. (2011), "Dewatering and composting aquaculture waste as a growing medium in the nursery production of tomato plants", Acta Horticulturae, Vol. 891, pp. 223229.

Dawood, M. F. A. and Azooz, M. M. (2019), "Concentration-dependent 
effects of tungstate on germination, growth, lignification-related enzymes, antioxidants, and reactive oxygen species in broccoli (Brassica oleracea var. italica L.)", Environmental Science and Pollution Research, Vol. 26, pp. 3644136457.

Delshad, M., Alifattahi, R., Taghavi, T. and Parsinezhad, M. (2011), "Improving water use efficiency in irrigation scheduling strawberries in soilless culture", Journal of Horticultural Science, Vol. 25, pp. $18-24$.

Fascella, G. (2015), "Growing substrates alternative to peat for ornamental plants", In: Asaduzzaman, M. D. (ed.), Soilless culture- use of substrates for the production of quality horticultural crops", In Tech, London, UK.

Gomez, K. A. and Gomez, A. A. (1984), Statistical procedure for agriculture research, $2^{\text {nd }}$ Ed., John Wily \& Sons Inc., New York, USA.

Grower, S. T. (1987) "Relations between mineral nutrient availability and fine root biomass in two Costa Rican tropical wet forests", Hypothesis Biotropica, Vol. 19 No. 2, pp.171175.

Gruda, N. (2009), "Do soilless culture systems have an influence on product quality of vegetables", Journal of Applied Botany and Food Quality, Vol. 82, pp. 141-147.
Grunert, O., Perneel, M. and Vandaele, S. (2008), "Peat-based organic grow bags as a solution to the mineral wool water problem", Mires and Peat, Vol. 3 No. 6, pp. 1-5.

Gutierrez, G. A. M., Altamirano, G. Z. and Urrestarazu, M. (2012), "Maguey bagasse waste as sustainable substrate in soilless culture by melon and tomato crop", Journal of Plant Nutrition, Vol. 35 , pp. 2135-2144.

Hasandokht, M. and Nosrati, S. (2010), "Effect of transplant age and fruit pruning on earliness and total yield of greenhouse cucumber (Cucumis sativus L. Cv. Sultan)", Plant Ecophysiology (Jiroft Branch), Vol. 2 No. 1, pp. 21-25.

Herrera, F., Castillo, J. E., Chica, A. F. and Lopez Bellido, L. (2008), "Use of municipal solid waste compost (MSWC) as a growing medium in the nursery production of tomato plants", Bioresource Technology, Vol. 99 pp. 287-296.

Hummel, R. L., Kuo, S. and Winters, D. (2000), "Fishwaste compost medium improves growth and quality of container-grown Marigolds and Geraniums without lesching", Environmental Horticulturae, Vol. 18 No. 2, pp. 93-98.

Jahromi, M. A., Aboutalebi, A. and Farahi, M. H. (2012), "Influence of different levels of garden compost (garden wastes and cow manure) on growth and stand establishment of 
tomato and cucumber in greenhouse condition", African Journal Biotechnology, Vol. 11 pp. 90369039.

Jensen, M. H. (1997), "Hydroponics", Horticulturae Science, Vol. 32, pp. 1018-1021.

Jeong, B. R. and Hwang, S. J. (2001), "Use of recycled hydroponic rockwool slabs for hydroponic production of cut rose", Acta Horticulturae, Vol. 554, pp. 89-94.

Johnson, J. R. H., Hochmuth, G. J. and Maynard, D. N. (2010), "Soilless Culture of Greenhouse Vegetables", Institute of Food and Agricultural Science, Vol. 218, pp. 19-22.

Kritsotakis, I. K. and Kabourakis, E. M. (2011), "Grape Vine Waste and Giant Reed Biomass Composts as Peat and Mineral Fertilizer Substitutes for Producing Organic Tomato Transplants", Journal of Crop Improvement, Vol. 25, pp. 664-679.

Lazcano, C., Arnold, J., Tato, A., Zaller, J. G. and Domi'nguez, J. (2009), "Compost and vermicompost as nursery pot components: effects on tomato plant growth and morphology", Spanish Journal and Agricultural Research, Vol. 7, pp. 944-951.

Lin, X., Zheng, J. and. Chen, Q. X. (2011), "Studies on tests and screening by vessel for light matrixes of sessile ficus microcarpa seedling. cultivation", Zhejiang News Report for Subtropical Crops, Vol. 29 No. 1, pp. 19-23.

Mathowa, T., Tshegofatso, N., Mojeremane, W., Matsuane, C., Legwaila, G. M. and O. Oagile, (2016), "Effect of commercial growing media on emergence, growth and development of tomato seedlings", International Journal of Agronomy and Agriculture Research, Vol. 9 No. 1, pp. 83-91.

Nair, A., Ngouajio, M. and Biernbaum, J. (2011), "Alfalfa-based organic amendment in peat compost growing medium for organic tomato transplant production", American Society for Horticultural Science, Vol. 46 No. 2, pp. 253-259.

Oagile, O., Ramalekane, O., Mojeremane, W., Matsuane, C., Legwaila, G. M. and Mathowa, T. (2016), "Growth and development response of Kale (Brassica oleracea var. Acephala L.) seedlings to different commercial growing media", International Journal of Plant \& Soil Science, Vol. 12 No. 4, pp. 1-7.

Olaria, M., Nebot, J. F., Molina, H., Troncho, P., Lapeña, L. and Llorens, E. (2016), "Effect of different substrates for organic agriculture in seedling development of traditional species of Solanaceae", Spanish Journal of Agricultural Research, Vol. 14 No. 1, pp. 80018013. 
Olle, M., Ngouajio, M. and Siomos, A. (2012), "Vegetable productivity as influenced by growing medium", $A$ review Agriculture, Vol. 99 No. 4, pp. 399-408.

Papamichalaki, M., Papadaki, A. and Tzortzakis, N. (2014), "Substitution of peat with municipal solid waste compost in watermelon seedling production combined with fertigation", Chilean Journal of Agriculture Research, Vol. 74, pp. 452-459.

Paul, L. C. and Metzger, J. D. (2015), "Impact of vermicompost on vegetable transplant quality", American Society for Horticultural Science, Vol. 40, pp. 2020-2023.

Ranal, M. A., Santana, D. G. D., Ferreira, W. R. and Mendes-Rodrigues, C. (2009), "Calculating germination measurements and organizing spreadsheets", Brazilian Journal of Botany, Vol. 32, pp. 849-855.

Reedy, S. 2005. In peat helping you? Grower talks, pp. 32-34.

Riaz, A., Arshad, M., Younis, A., Raza, A. and Hameed, M. (2008), "Effects of different growing media on growth and flowering of zinnia elegans cv. blue point", Pakistan Journal of Botany, Vol. 40, pp. 1579-1585.

Schmilewski, G. (2009), Growing medium constituents used in the EU. International Symposium on Growing Media, Vol. 819, pp. 33-
45.

Sevgican, A. (1999), Protected vegetable growing soilless culture II, Agriculture Faculty, Ege University, Izmir, Turkey, Vol. 528, pp. 384 392.

Subler, S., Edwards, C.A. and Metzger, J. (1998), "Comparing vermicomposts and composts", BioCycle, Vol. 39, pp. 63-66.

Tam, N. V. and Wang, C. H. (2015), "Use of spent mushroom substrate and manure compost for honeydew melon seedlings", Journal of Plant Growth Regulation, Vol. 34, pp. 417-422.

Urlic, B., Runjic, M. and Dumicic, G. (2015), "Olive mill waste compost as a peat substrate in leafy vegetables transplant", Agricultural \& Forestry, Vol. 61 No. 3, pp. 3542.

Vaughn, S. F., Deppe, N. A., Palmquist, D. E. and Berhow, M. A. (2011), "Extracted sweet corn tassels as renewable alternative to peat in greenhouse substrates", Industrial Crops and Products, Vol. 33 No. 3, pp. 514-517.

Verdonck, O., De Vleeschauwer, D. and De Boot, M. (1982), "The influence of substrate on plant growth", Acta Horticulturae, Vol. 126, pp. 251- 
258.

Yilmaz, E., Sonmez, I. and Demir, E. (2014), "Effects of zeolite on seedling quality and nutrient contents of cucumber plant (Cucumis sativus L. cv. Mostar F1) grown in different mixtures of growing media", Communications in Soil Science and Plant Analysis, Vol. 45, pp. 2767-2777.

Youssefian, Z., Mobli, M. and Aghdak, P. (2009), Effect of different planting bed and hydrogel on vegetative and reproductive traits Cherry, First National Congress of the Hydroponic and Greenhouse Production (In Persian), Isfahan, Iran, pp. 28-30. 